\title{
ГИСТОЛОГО-БИОХИМИЧЕСКИЕ АСПЕКТЫ СОЧЕТАННОГО ВЛИЯНИЯ НЕКОТОРЫХ ЕСТЕСТВЕННЫХ МЕТАБОЛИТОВ НА ОБЩУЮ РЕЗИСТЕНТНОСТЬ У ЯИЧНЫХ ЦЫПЛЯТ
}

\author{
И.С. ЛУГОВАЯ, Т.О. АЗАРНОВА, И.И. КОЧИШ, С.Ю. ЗАЙЦЕВ, \\ М.С. НАЙДЕНСКИЙ, А.А. АНТИПОВ
}

\begin{abstract}
Известно, что промышленное инкубирование яиц, сопровождающееся различными стрессовыми воздействиями, приводит к ранней эмбриональной гибели. В связи с этим актуально применение экологически безопасных способов профилактики негативных стрессовых воздействий уже в эмбриогенезе. Целью настоящей работы было изучение влияния естественных метаболитов на гистологическую структуру фабрициевой сумки и общую резистентность цыплят. Исследования проводили на инкубационных яйцах кур (Gallus gallus) яичного кросса Шейвер 2000 (Shaver 2000, «Hendrics Genetics Company», Голландия) в условиях ФГУП ППЗ «Птичное», (Московская обл.) в 2011 году. За 3-4 ч перед закладкой в инкубатор на поверхность скорлупы из пульверизатора наносили водный раствор коламина, янтарной кислоты и серина в концентрациях соответственно 0,$1 ; 0,1$ и $0,2 \%$, а на 19 -е сут $-0,1 \%$ водный раствор коламина. Препараты предварительно растворяли в дистиллированной воде при 18-22 ${ }^{\circ}$ С. В качестве контроля использовали партию яиц, которую не подвергали обработкам. В каждую партию входило по 544 яйца. Учитывали показатели вывода цыплят и выводимости яиц, количество отходов инкубации, а также брали кровь для определения содержания иммуноглобулинов, активности лизоцима и бактерицидной активности. В 1-суточном возрасте у цыплят отбирали образцы тканей фабрициевой сумки для гистологического анализа $(n=5)$. Трансовариальная обработка яиц биологически активными метаболитами положительно влияла на жизнеспособность эмбрионов и молодняка кур в онтогенезе, что было обусловлено нивелированием реакций оксидативного стресса и стимуляцией центральных составляющих резистентности - иммунного ответа и неспецифической защиты у цыплят 1-суточного возраста. Коламин благодаря способности превращаться в фосфатидилхолин и фосфатидилэтаноламин, а серин - за счет превращения в фосфатидилсерин нивелируют деструкцию мембран клеток, возникающую при активации свободнорадикального окисления на фоне стресса. Янтарная кислота, будучи энергетическим субстратом и антигипоксантом, профилактирует недостаток энергии в виде АТФ, возникающий в критические периоды эмбриогенеза цыплят. Применяемые в комплексе биологически активные вещества, способны оптимизировать условия существования эмбриона во время искусственной инкубации, сопровождающейся технологическими стрессами. Высокая жизнеспособность цыплят опытной группы отразилась на снижении всех категорий отходов инкубации, что повлекло увеличение показателей вывода цыплят и выводимости яиц. Содержание иммуноглобулинов, отвечающих за первичный и вторичный иммунный ответ, также возросло, что было проявлением иммуномодулирующего действия. При этом содержание IgE осталось неизменным, что свидетельствует об отсутствии реакций гиперчувствительности. Также коламин, янтарная кислота и серин способствовали активации факторов неспецифической защиты в виде бактерицидной активности сыворотки крови и лизоцима, которые возросли в опытной групाе цыплят. Композиция биологически активных веществ положительно повлияла на гистоархитектонику фабрициевой сумки. При этом выявляли признаки физиологической внутриклеточной гиперплазии, а также отсутствие инволютивных процессов в органе. Отмечено последействие композиции, которое выражалось в увеличении сохранности молодняка кур в течение первых 60 сут выращивания за счет снижения падежа. Таким образом, коламин, янтарная кислота и серин способны не только профилактировать оксидативный стресс, но и оказывать положительное влияние на общую резистентность у яичных цыплят.
\end{abstract}

Ключевые слова: цыплята, эмбриогенез, антиоксиданты, перекисное окисление липидов, активный иммунитет, фабрициева сумка, вывод цыплят, этаноламин, янтарная кислота, серин.

Одна из главных задач современного птицеводства - получение высоких производственных показателей, в том числе вывода цыплят, что достижимо только при адекватном, своевременном становлении антиоксидантных систем и систем резистентности организма птицы (1). Неравномерный прогрев яиц в партии, овоскопирование, отсутствие аэроионизации, биоакустики, возможные сбои в работе инкубаторов и другие технологические стрессы препятствуют полноценному формированию эмбрионов, приводят к их ранней массовой гибели или получению ослабленно- 
го, некачественного молодняка (2-4). В частности, в ряде работ доказано, что на показатели биологического контроля влияет содержание газов (5-7) температура $(8,9)$, влажность в инкубаторе $(10)$.

Развивающийся и растущий организм гораздо более чувствителен к воздействию факторов окружающей среды по сравнению с взрослым, поскольку его антиоксидантные, иммунные и другие системы, а также неспецифическая защита еще недостаточно сформированы и не могут противостоять действию стрессоров в полной мере (11-15). В развитии эмбрионов существуют критические периоды, поэтому молодняк, получаемый в ненадлежащих производственных условиях, нередко имеет низкий потенциал резистентности, а значит, жизнеспособности и продуктивности (16).

У цыплят периферические органы иммунной системы (селезенка и лимфоидный дивертикул) морфофункционально развиваются в течение всего постэмбриогенеза, причем к 42-м сут этот процесс не завершается. К моменту вылупления сформированными морфологически и функционально оказываются только центральные органы иммунной системы - тимус и фабрициева сумка (17). Поскольку фабрициева сумка играет ключевую роль в формировании иммунитета птицы, изучение ее морфофункциональных характеристик в связи с поиском эффективных методов профилактики последствий стрессовых воздействий, возникающих при промышленном инкубировании яиц, рассматривается как одна из важнейших задач (18). В фабрициевой сумке из стволовых клеток костного мозга формируется популяция клонов В-лимфоцитов, которые покидают бурсу и заселяют тимуснезависимые зоны периферических органов и структур иммунной системы, где под влиянием антигенов дифференцируются и превращаются в антителосинтезирующие плазматические клетки (19).

Для экстремальных стрессовых состояний различной этиологии характерна преждевременная инволюция и атрофия фабрициевой сумки, что можно рассматривать как морфологический эквивалент приобретенного иммунодефицита (20). По данным Е.Г. Турицыной (20), модификации гистоструктуры в фабрициевой сумке также могут быть связаны с антигензависимым ответом иммунной системы на проведенные вакцинации и развитие инфекций (при этом наблюдаются изменения в количестве иммуноглобулинов в сыворотке крови цыплят). При иммунизации и инфекциях возможны изменения размеров и формы бурсы, уменьшение числа лимфатических фолликулов, истончение коркового слоя, разрастание соединительной ткани, обильная инфильтрация органа макрофагами и гранулоцитами (20).

Иммуноморфологические исследования - один из информативных приемов оценки работы иммунной системы (21). Этим определяется интерес к изучению гистоструктуры иммунокомпетентных органов, непосредственно вовлеченных в иммунобиологические реакции (в частности, фабрициевой сумки), как в практической, так и в фундаментальной биологии.

Установлено, что технологические факторы выращивания птицы оказывают значительное влияние на гистоструктуру фабрициевой сумки. По данным Н.А. Травниковой (22), у цыплят при клеточном способе содержания в условиях высокой плотности посадки наблюдается комплекс патологических процессов. В просветах бурсы скапливаются лейкоциты, псевдоэозинофилы, макрофаги и гнойные тельца. В субэпителиальном слое бурсы обнаруживается тот же клеточный инфильтрат, что и в просвете (22). Различные добавки к корму способствуют активации иммунитета, что положительно отражается на гистокартине иммунокомпетентных органов (23). Так, при использовании пробиотических препаратов масса органов иммунной защиты возрастает за счет физиологической гиперплазии 
(24). Уже в эмбриогенезе можно нивелировать нарушения микроструктуры фабрициевой сумки. Например, введение внутрь яйца иммуномодулятора (метизопринола) способствует положительным изменениям в гистоструктуре этого органа (25).

Следует отметить, что морфологические, гистологические и биохимические показатели состояния фабрициевой сумки изучали преимущественно в позднем онтогенезе. В этой связи особый интерес представляет комплексное исследование органа в раннем постэмбриогенезе, то есть сразу после вывода цыплят.

Изученная нами в предыдущей работе композиция биологически активных веществ (БАВ) положительно влияла на количество клеток крови, некоторые из которых были продуцентами факторов неспецифической защиты организма, например лизоцима (26). Чтобы более полноценно исследовать функционирование иммунной системы необходимо оценить не только гистологическое состояние фабрициевой сумки при использовании разработанной композиции, но также определить содержание иммуноглобулинов в крови цыплят, которое позволит обнаружить наличие или отсутствие иммуномодулирующего эффекта.

Роль иммуноглобулина М (IgM) в иммунных ответах краткосрочна и представляет первичную реакцию организма на любой патоген. IgY y кур во многом сходен с IgG млекопитающих по строению и функциям, при этом оба определяются одним и тем же иммунотурбидиметрическим методом, что позволяет использовать последний для оценки иммунитета птицы (27). IgA - основная форма антител в секретах организма (28). Необходимо отметить, что иммуноглобулин D у птиц отсутствует, поскольку у них нет кодирующих его генов (29).

Также известно, что среди всех видов птиц у кур гуморальный ответ самый сильный (30). Сообщалось, что естественные антитела присутствуют даже у тех кур, которые не были иммунизированы (31). Было сделано заключение, что они могут играть важную роль как в инициации, так и в регуляции специфических гуморальных иммунных реакций у домашней птицы (32). При этом период полураспада иммуноглобулинов у суточных цыплят колеблется в пределах 3 сут (33).

Именно поэтому интересно определить количественные изменения естественных антител под воздействием различных соединений в период эмбриогенеза для выявления их возможного иммуномодулирующего эффекта. Нами разработан метод стимуляции эмбрионального развития кур, повышающий неспецифическую резистентность, который включает трансовариальную обработку яиц композицией естественных метаболитов, состоящей из коламина, янтарной кислоты и серина. Общеизвестно, что аномальная интенсификация свободнорадикальных реакций приводит к чрезмерной активизации перикисного окисления липидов (ПОЛ) и повреждению билипидных мембран. Коламин в организме животных и птицы легко превращается в фосфатидилэтаноламин и фосфатидилхолин, серин редко расходуется на синтез этаноламина (34) и в первую очередь служит компонентом фосфатидилсерина или донором углеродного скелета в биохимических процессах. Эффективность этих элементов в композиции практически подтверждена в серии экспериментов (35). Поскольку процессы синтеза энергозатратны, в композицию добавлена янтарная кислота как основной интермедиат цикла трикарбоновых кислот и субстрат биологического окисления, естественный пул которой быстро истощается при любых средних и сильных стрессах. Янтарная кислота поддерживает синтез АТФ как в цикле Кребса, так и в митохондриальной дыхательной це- 
пи, компенсируя снижение количества АТФ, характерное для состояния стресса. Важно отметить, что не только сукцинат, но и коламин (через холин) в организме способны профилактировать нарушения в работе митохондриальной дыхательной цепи, препятствуя энергетическим потерям и чрезмерному синтезу активных форм кислорода $(34,36)$.

Следует отметить, что именно иммунная система птиц наиболее уязвима к стрессу и первой испытывает последствия избыточной генерации свободнорадикальных частиц. Применение антиоксидантных препаратов препятствует образованию деструктивных изменений в билипидном каркасе мембран (37). Предложенная композиция метаболитов, обладающая выраженным антиоксидантным действием (35), способна эффективно препятствовать избыточной генерации свободных радикалов и снижать интенсивности липопероксидации в организме цыплят, сохраняя структурную целостность внутренних органов, в том числе фабрициевой сумки.

В настоящей работе впервые выявлены особенности изменений специфической и неспецифической резистентности (содержание иммуноглобулинов, лизоцима, бактерицидная активность сыворотки крови), а также гистоархитектоники фабрициевой сумки при использовании предложенной нами композиции метаболитов.

Целью работы было изучение влияния естественных метаболитов на гистологическую структуру фабрициевой сумки и общую резистентность полученных цыплят.

Методика. Исследования (ФГУП ППЗ «Птичное», Московская обл., 2011 год) проводили на инкубационных яйцах кур (Gallus gallus) яичного кросса Шейвер 2000 (Shaver 2000, «Hendrics Genetics Company», Голландия). Оптимальная композиция естественных метаболитов и кратность обработки были подобраны ранее $(26,37)$. Опытную партию яиц обрабатывали двукратно. За 3-4 ч перед закладкой в инкубатор на поверхность скорлупы из пульверизатора наносили водный раствор коламина, янтарной кислоты и серина в концентрациях соответственно 0,1; 0,1 и 0,2 \%, а на 19-е сут - 0,1 \% водный раствор коламина. Препараты предварительно растворяли в дистиллированной воде при 18-22 ${ }^{\circ} \mathrm{C}$. В качестве контроля использовали партию яиц, которую не подвергали обработкам («сухой» контроль»), поскольку было доказано, что в таком случае результаты не отличаются от «влажного контроля» (38).

В каждую партию входило по 544 яйца. Учитывали показатели вывода цыплят и выводимости яиц, количество отходов инкубации. Для определения сохранности цыплят выращивали по 100 гол. от каждой группы при стандартных условиях. В цельной крови, взятой у 1-суточных цыплят после декапитации, определяли содержание иммуноглобулинов иммунотурбидиметрическим методом, в сыворотке - активность лизоцима (нефелометрическим методом) и бактерицидную активность (БАСК) фотоэлектронефелометрическим методом (39).

В 1-суточном возрасте у цыплят отбирали образцы тканей фабрициевой сумки для гистологического анализа $(n=5)$. Образцы органов заливали в парафин и готовили гистологические срезы толщиной 5-7 мкм на микротоме МПС-2 (ОАО Х3 «Точмедприбор», Россия) по общепринятым методикам (40) с последующим окрашиванием гематоксилином Майера и эозином. Микроскопию полученных гистологических срезов осуществляли при помощи биологического микроскопа ScienOpBP-52 («ScoреТес», Китай) при увеличении окуляров $7 \times, 10 \times$ и объективов $\times 4, \times 10$ и $\times 40$. Фотографии делали цифровой камерой-окуляром для микроскопа DCM800 («ScopeTec», Китай, 8000 pixels, USB2.0). Морфометрию проводи- 
ли при помощи окуляр-микрометра с использованием программы ImageJ (National Institutes of Health, США) с набором модулей для медицинской морфометрии. Измерения выполняли при общем увеличении $\times 70$ в 30 последовательных полях, равных площади окулярной сетки.

Данные обрабатывали статистически в программе Microsoft Excel. Рассчитывали средние $(M)$ и стандартные ошибки средних ( $\pm \mathrm{SEM})$. Достоверность различий оценивали по $t$-критерию Стьюдента.

Результаты. Проницаемость скорлупы яиц для биологически активных веществ была научно доказана Р.Х. Кармолиевым с соавт. (41). Использование естественных метаболитов приводило к снижению аномальной интенсивности свободно-радикальных реакций, а также процессов липопероксидации у молодняка опытной группы и, как следствие, к оптимизации обменных процессов (42). Это определило значимое повышение эмбриональной жизнеспособности, выразившееся в снижении количества отходов инкубации при достоверном увеличении вывода цыплят на $9,38 \%$ (р $\leq 0,001)$ (в контроле и опыте соответственно 75,0 и 84,38 \%) и выводимости яиц на 9,26 \% (p $\leq 0,001)(81,27$ и 90,53\%).

Следует отметить, что высокая жизнеспособность особей опытной группы сохранилась в течение длительного периода постэмбрионального развития. При выращивании молодняка по 100 гол. в группе в течение 60 сут, охватывающих основные критические периоды постэмбрионального развития, падеж в опытной группе снизился в 1,2 раза при увеличении сохранности на $1 \%$ (в контроле и опыте соответственно 94 и $95 \%$ ).

Указанные положительные эффекты наблюдались на фоне повышения активного иммунитета, то есть зафиксированные в опытной группе показатели содержания иммуноглобулинов были оптимальным для изученных особей. Показатели специфической защиты организма у 1-суточных цыплят в опытной группе были выше, чем в контроле (табл. 1).

1. Содержание иммуноглобулинов (г/мл) в сыворотке крови у 1-суточных цыплят (Gallus gallus) кросса Шейвер 2000 при обработке яиц композицией метаболитов (ФГУП ППЗ «Птичное», 2011 год)

\begin{tabular}{l|cc}
\hline \multirow{2}{*}{ Иммуноглобулин } & \multicolumn{2}{|c}{ Группа } \\
\cline { 2 - 3 } & контроль $(n=5)$ & опыт $(n=5)$ \\
\hline IgM & $0,300 \pm 0,007$ & $0,330 \pm 0,008^{*}$ \\
IgG $(\mathrm{IgY})$ & $3,000 \pm 0,100$ & $3,300 \pm 0,070$ \\
IgA & $0,250 \pm 0,009$ & $0,260 \pm 0,007$ \\
IgE & $1,1000 \pm 0,01$ & $1,100 \pm 0,020$ \\
П р и м е ч а н и е. Описание групп см. в разделе «Методика». \\
* Различия с контролем статистически значимы при $\mathrm{p}<0,05$. \\
\hline
\end{tabular}

Содержание IgM, отвечающего за первичный иммунный ответ, у цыплят из опытной группы оказалось достоверно выше (на $10 \%$, $\mathrm{p}<0,05)$, при этом количество IgG $(\operatorname{IgY})$, определяющего вторичный иммунный ответ, также увеличилось на $10 \%$ (см. табл. 1). Незначительно (на 4 \%) повышалась концентрация IgA, а содер-

жание IgE оставалось неизменным. Эти данные свидетельствует об иммуномодулирующем действии применяемой композиции на фоне оксидативного стресса при инкубации. Проявления гиперчувствительности отсутствовали, о чем свидетельствуют равнозначные в контроле и опыте показатели по IgE. На иммуномодулирующее синергическое действие исследуемых БАВ также указывало повышение содержания факторов неспецифической защиты - БАСК (на 3,8 \%) и лизоцима (на 4,8 \%).

Высокая реактивность организма у цыплят из опытной группы была следствием позитивного влияния естественных метаболитов на гистоархитектонику фабрициевой сумки (табл. 2, рис.).

Как видно из данных таблицы 2, объемная плотность стромы фабрициевой сумки у цыплят из обработанных яиц на $11,4 \%$ достоверно меньше, а объемная плотность мозговой зоны фолликулов - на $29 \%$ 
больше, чем в контроле. Достоверно уменьшилась плотность мозговой зоны фолликулов (на 17 \%), увеличилась площадь корковой зоны и уменьшилась - мозговой (соответственно в 2,12 и 2,69 раза по сравнению с контролем). Как следствие, повысился корково-мозговой индекс (КМИ), который отражает функциональную активность органа: чем индекс больше, тем лучше функционирует орган (43). В нашем исследовании в опытной группе КМИ превышал контрольные показатели в 5,72 раза. Полученные данные согласуются с микроморфологическими результатами гистологического исследования органа (см. рис.).

2. Морфометрические показатели фабрициевой сумки у 1-суточных цыплят (Gallus gallus) кросса Шейвер 2000 при обработке яиц композицией метаболитов (ФГУП ППЗ «Птичное», 2011 год)

\begin{tabular}{|c|c|c|}
\hline Показатель & Контроль $(n=5)$ & Опыт $(n=5)$ \\
\hline \multicolumn{3}{|l|}{ Объемная плотность, \%: } \\
\hline стромы & $35,00 \pm 1,22$ & $23,60 \pm 1,08^{*}$ \\
\hline корковой зоны фолликулов & $30,00 \pm 1,00$ & $59,00 \pm 2,35^{* *}$ \\
\hline мозговой зоны фолликулов & $35,00 \pm 1,38$ & $18,00 \pm 0,89^{* *}$ \\
\hline \multicolumn{3}{|l|}{ Площадь, ×106 мкм²: } \\
\hline фолликула & $7291,138 \pm 440,780$ & $9360,420 \pm 798,910$ \\
\hline корковой зоны & $3680,440 \pm 349,870$ & $7818,922 \pm 602,680^{* *}$ \\
\hline мозговой зоны & $3703,168 \pm 387,320$ & $1374,432 \pm 83,240^{* *}$ \\
\hline Корково-мозговой индекс & 99,39 & 568,88 \\
\hline
\end{tabular}
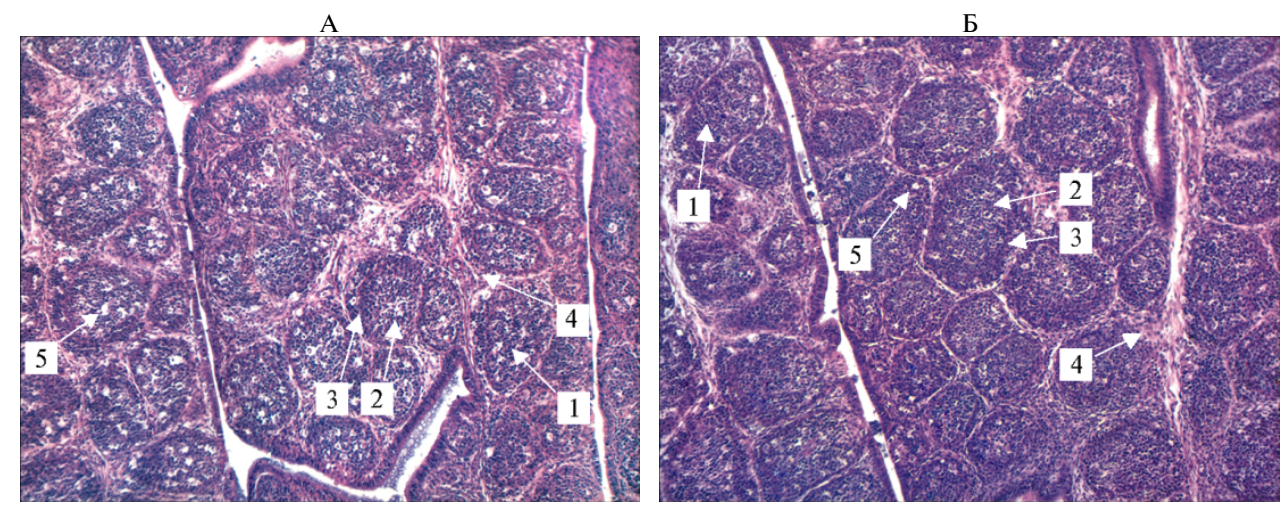

Гистологическая структура фабрициевой сумки у 1-суточных цыплят (Gallus gallus) кросса Шейвер 2000 из контрольной (А) и опытной (Б) группы: 1 - лимфатический узелок, 2 - медуллярная часть, 3 - кортикальная часть, 4 - соединительнотканные элементы стромы, 5 мелкие кистозные полости (окрашивание гематоксилином и эозином; микроскоп ScienОрВР-52, «SсореТес», Китай; окуляр ×10, объектив $\times 10)$.

У цыплят контрольной группы в бурсе фабрициевой сумки прослеживался выраженный инволюционный процесс. Капсула органа была утолщена, трабекулярный рисунок резко выражен за счет увеличения соединительнотканных элементов стромы (фиброцитов, фибробластов и межклеточных волокнистых структур). Просвет бурсы выстлан многорядным цилиндрическим эпителием без признаков повреждения. Непосредственно за эпителиальным слоем в толще слизистой оболочки залегали множественные замкнутые лимфоидные фолликулы преимущественно среднего и мелкого размера, имеющие округлую, овальную или трапециевидную форму и нечетко выраженное разделение на корковую и мозговую зоны. Лимфатические узелки прилегали друг к другу и располагались в складках в один-два ряда. Корковая зона была истончена, имела вид узкой полоски, лежащей по периферии фолликулов на границе со стромой органа, была представлена скоплением небольшого количества малых лимфо- 
цитов. Более светлая мозговая зона состояла из редко расположенных больших лимфоцитов и отдельных плазматических клеток, а также большого количества макрофагов и гранулоцитов. Среди лимфоцитов часто встречались апоптотические тельца. В фолликулах наблюдались четко выраженные многочисленные мелкие кистозные полости. При этом в органе не было выраженных признаков нарушения гемодинамики.

У цыплят контрольной группы капсула фабрициевой сумки не была утолщена, трабекулярный рисунок плохо выражен за счет слабого развития соединительнотканных элементов стромы. Просвет бурсы был выстлан многорядным цилиндрическим эпителием без признаков повреждения. Непосредственно за эпителиальным слоем в толще слизистой оболочки залегали множественные замкнутые лимфоидные фолликулы преимущественно крупного и среднего размера, имеющие округлую, овальную или трапециевидную форму. Лимфатические узелки прилегали друг к другу и располагались в складках в три-четыре ряда. Корковая зона занимала большую площадь фолликула, распространяясь от центра к периферии, и была представлена в основном относительно плотным скоплением малых лимфоцитов. Центрально расположенная мозговая зона более светлая, относительно слабо развита, включала в себя большие лимфоциты, плазматические клетки, а также небольшое количество макрофагов и отдельных гранулоцитов. В фолликулах наблюдались редкие единичные очаги поликистозного процесса, апоптотические тела встречались редко.

В процессе гистологических исследований у цыплят опытной группы был установлен ряд положительных изменений относительно контроля. Так, у молодняка контрольной группы были обнаружены признаки, указывающие на снижение функциональной активности фабрициевой сумки. Они характеризовались увеличением доли соединительной ткани в органе, небольшим размером лимфоидных фолликулов с развитием процессов делимфатизации в корковом и мозговом слое. При этом образование микрокистозных полостей и увеличение количества макрофагов в мозговом слое фолликулов явно указывало на гибель лимфоцитов. Отсутствие выраженной воспалительной реакции в органе дало повод предполагать, что процесс гибели лимфоцитов произошел за счет апоптоза, а не некроза, что позволяет рассматривать неинфекционные факторы в качестве причины этого процесса (43). Это также подтверждается увеличением количества апоптозных телец, которые мы обнаружили в лимфоидных фолликулах фабрициевой сумки при гистологическом исследовании.

Данные литературы $(44,45)$ свидетельствуют, что влияние неспецифических факторов внешней среды (несовершенство процессов инкубации яиц, кормления и содержания несушек) на формирование органов у цыплят в процессе эмбрионального развития достаточно высоко. Вследствие таких неблагоприятных воздействий нарушается процесс становления иммунокомпетентных органов, что проявляется снижением неспецифической резистентности и иммунологической реактивности.

В развитии фабрициевой сумки у цыплят различают несколько стадий: роста (до 2-недельного возраста), зрелости (до 5-8 нед), ранней инволюции (до 9-15 нед), поздней инволюции (до 25-30 нед), остаточную (после 30 нед) до полного исчезновения (46). Учитывая, что в опыте были использованы цыплята 1-суточного возраста, можно утверждать о рано начавшихся процессах атрофии фабрициевой сумки, или так называемой акцидентальной инволюции органа. При этом происходило быстрое уменьшение ее массы и объема, прежде всего под влиянием глюкокортикостероидов в различных стрессовых ситуациях. В наших исследованиях масса 
фабрициевой сумки в опыте составила $0,084 \pm 0,002$ г, в контроле $0,069 \pm 0,001$ г (разница между опытом и контролем $-21,7 \%, \mathrm{p}<0,001)$.

Воздействие стресс-факторов на эмбрион, а затем в постэмбриональный период на цыпленка приводит к формированию вторичного иммунодефицита, выражающегося неполноценностью развития морфологической структуры иммунокомпетентных органов (46).

При гистологическом исследовании фабрициевой сумки цыплят опытной группы, были выявлены признаки умеренно развитой физиологической гиперплазии органа при отсутствии процессов инволюции. Гиперплазия выражалась в увеличении размеров лимфоидных фолликулов органа за счет увеличения количества лимфоцитов при сохранении формы и структурных элементов, составляющих фолликулы. Увеличение размеров фолликулов происходило прежде всего благодаря увеличению коркового слоя, в то время как мозговой слой отличался небольшим размером и достаточно редкими процессами апоптоза среди лимфоцитов. В совокупности эти данные указывают на полноценное развитие органа, характерное для цыплят в данный возрастной период.

Таким образом, обработка яиц кур композицией естественных метаболитов способствует более полноценному, своевременному становлению всех структур центрального органа иммунитета птицы, снижает эмбриональную гибель, положительно влияет на общую резистентность цыплят, определяет высокое качество и сохранность молодняка. У 1-суточных цыплят в фабрициевой сумке были не только не зафиксированы выраженные инволютивные процессы, но выявлены признаки физиологической внутриклеточной гиперплазии. То есть комплекс естественных метаболитов оптимизирует гистоархитектонику фабрициевой сумки.

\section{ЛИТЕРАТУРА}

1. Васильев С.С., Корнева Г.В. Морфофункциональные изменения в иммунной системе цыплят бройлеров в процессе выращивания. Ученые записки Казанской государственной академии ветеринарной медицины им. Н.Э. Баумана, 2010, 201: 182-186.

2. Zakarial H., Al-Anezi M.A. Effect of ascorbic acid and cooling during egg incubation on hatchability, culling, mortality, and the body weights of broiler chickens. Poultry Science, 75, 1996: 1204-1209 (doi: 10.3382/ps.0751204).

3. Zulkifli I., Siegel P. Is there a positive side to stress? World's Poultry Science Journal, 1995, 51(1): 63-76 (doi: 10.1079/WPS19950006).

4. Reijrink I.A.M., Meijerhof R., Kemp B., Graat E.A.M., van den Brand H. Influence of prestorage incubation on embryonic development, hatchability, and chick quality. Poultry Science, 2009, 88: 2649-2660 (doi: 10.3382/ps.2012-02816).

5. Everaert N., Kamers B., Witters A., De Smit L., Debonne M., Decuypere E., Bruggeman V. Effect of four percent carbon dioxide during the second half of incubation on embryonic development, hatching parameters, and posthatch growth. Poultry Science, 2007, 86: 1372-1379 (doi: 10.1093/ps/86.7.1372).

6. Everaert N., De Smit L., Debonne M., Witters A., Kamers B., Decuypere E., Bruggeman V. Changes in acid-base balance and related physiological responses as a result of external hypercapnia during the second half of incubation in the chicken embryo. Poultry Science, 2008, 87: 362-367 (doi: 10.3382/ps.2007-00345).

7. Molenaar R., van den Anker I., Meijerhof R., Kemp B., van den Brand H. Effect of eggshell temperature and oxygen concentration during incubation on the developmental and physiological status of broiler hatchlings in the perinatal period. Poultry Science, 2011, 90: 1257-1266 (doi: 10.3382/ps.2010-00684).

8. Shim M.Y., Pesti G.M. Effects of incubation temperature on the bone development of broilers. Poultry Science, 2011, 90: 1867-1877 (doi: 10.3382/ps.2010-01242).

9. Willemsen H., Li Y., Willems E., Franssens L., Wang Y., Decuypere E., Everaert N. Intermittent thermal manipulations of broiler embryos during late incubation and their immediate effect on the embryonic development and hatching process. Poultry Science, 90(6), 2011: 1302-1312 
(doi: 10.3382/ps.2011-01390).

10. Van der Pol C.W., van Roovert-Reijrink I.A.M., Maatjens C.M., van den Brand H., Molenaar R. Effect of relative humidity during incubation at a set eggshell temperature and brooding temperature posthatch on embryonic mortality and chick quality. Poultry Science, 2013, 92: 2145-2155 (doi: 10.3382/ps.2013-03006).

11. Wang F.C., Fang C.G., Zhang Y.H., Wang H.B., Han Y.C. Effects of compound chinese herbal immune synergist on immunity of egg-laying chicken. Acta Veterinaria et Zoot echnica Sinica, 2006, 37(2): 187-192.

12. Akbarian A., Michiels J., Degroote J., Majdeddin M., Golian A., De Smet S. Association between heat stress and oxidative stress in poultry; mitochondrial dysfunction and dietary interventions with phytochemicals. J. Anim. Sci. Biotechno., 2016, 7(37): 1-14 (doi: 10.1186/s40104016-0097-5).

13. Aughey E. Comparative veterinary histology with clinical correlates. Manson Publishing, The Veterinary Press, 2010.

14. Betteridge D.J. What is oxidative stress? Metabolism, 2000, 49(2): 3-8 (doi: 10.1016/S00260495(00)80077-3).

15. Sies H. Oxidative stress: from basic research to clinical application. Amer. J. Med., 1991, 91: 315-385 (doi: 10.1016/0002-9343(91)90281-2).

16. Щербатов В.И., Смирнова Л.И., Щербатов О.В. Инкубация яиц сельскохозяйственной птицы: монография. Краснодар, 2015.

17. Селезнев С.Б., Овсищер Л.Л. Структурно-функциональные связи между иммунной и репродуктивной системами птиц. Вестник Российского университета дружбы народов. Серия: Агрономия и животноводство, 2007, 1-2: 48-53.

18. Смердова М.Д., Вахрушева Т.И. Особенности морфогенеза фабрициевой бурсы у петушков и курочек в возрасте от 1 до 180 суток под влиянием адаптогенов животного и растительного происхождения. Вестник Красноярского государственного аграрного университета, 2010, 12(51): 106-110.

19. Якименко Л.Л., Якименко В.П. Современные представления о фабрициевой бурсе птиц. Ученые записки учреждения образования «Витебская ордена «Знак почета» государственная академия ветеринарной медицинь», 2011, 47(1): 321-323.

20. Турицына Е.Г. Морфологические особенности фабрициевой бурсы цыплят в норме и при экстремальных состояниях. Международный вестник ветеринарии, 2010, 1: 44-48.

21. Сандул П.А., Луппова И.М., Сандул А.В. Морфофункциональная характеристика тимуса и фабрициевой бурсы цыплят при введении в рацион е-витаминных добавок. Ученые записки учреждения образования «Витебская ордена «Знак почета» государственная академия ветеринарной медицины», 2011, 47(1): 293-296.

22. Травникова Н.А., Дроздова Л.И. Морфология фабрициевой бурсы цыплят при разных способах содержания. В сб.: Молодежь и наука. М., 2000: 126-128.

23. Муллакаев А.О., Шуканов А.А. Оценка гистокартины органов иммунной системы у бройлеров при назначении природных цеолитов. Вестник Чувашского государственного педагогического университета им. И.Я. Яковлева, 2012, 4(76): 120-123.

24. Сковородин Е.Н., Деблик А.Г., Маликова А.Р., Ижбулатова Д.А. Влияние пробиотиков на функциональную морфологию органов цыплят. Нива Поволжья, 2006, 1(1): 45-48.

25. Tykałowski B., Stenzel T., Lewczuk B., Andrzejewski M., Koncicki A. Effect of methisoprinol administered in ovo on the histological structure of the bursa of Fabricius in turkeys. Bulletin Veterinary Institute in Pulawy, 2009, 53(3): 471-476.

26. Yartseva I.S., Azarnova T.O., Indyukhova Ye. N., Kochish I. I., Naydenskiy M.S. Antioxidant Properties of Ethanolamine, Succinic Acid and Serine when Treating Hatching Eggs. Journal of Biological \& Scientific Opinion, 2013, 1(3): 154-156 (doi: 10.7897/2321-6328.01304).

27. Ratcliffe M.J.H. Allotype suppression in the chicken. V. Abnormal isotype ratios of chronically suppressed IgM and IgG allotypes. Cell. Immunol., 1984, 83: 208-214.

28. Mansikka A. Chicken IgA H chains. Implications concerning the evolution of $\mathrm{H}$ chain genes. $J$. Immunol., 1992, 149(3): 855-861.

29. Манько В.М., Девришов Д.А. Ветеринарная иммунология. Фундаментальные основы. М., 2011.

30. Higgins D.A. Comparative immunology of avian species. In: Poultry immunology. Carfax Publishing Company, Abingdon, UK, 1996.

31. Parmentier H.K., Lammers A., Hoekman J.J., Vries Reilingh G. De, Zaanen I.T., Savelkoul H.F. Different levels of natural antibodies in chickens divergently selected for specific antibody responses. Dev. Comp. Immunol., 2004, 28(1): 39-49 (doi: 10.1016/S0145-305X(03)00087-9).

32. Lammers A., Klomp M.E.V., Nieuwland M.G.B., Savelkoul H.F.J., Parmentier H.K. Adoptive transfer of natural antibodies to non-immunized chickens affects subsequent antigen-specific and cellular immune responses. Dev. Comp. Immunol., 2004, 28(1): 51-60 (doi: 10.1016/S0145$305 X(03) 00102-2)$. 
33. Patterson R., Youngner J.S., Weigle W.O., Dixon F.J. The metabolism of serum proteins in the hen and chick and secretion of serum proteins by the ovary of the hen. J. Gen. Physiol., 1962, 45: 501-513.

34. Марри Р., Греннер Д., Мейе П. Биохимия человека. М., 2009.

35. Азарнова Т.О., Кочиш И.И., Найденский М.С., Зайцев С.Ю., Ярцева И.С. Мембранопротекторные, обменостимулирующие и антиоксидантные свойства комплекса естественных метаболитов: серина, сукцината и коламина. Прикладная аналитическая химия, 2012, 1(7): 46-49.

36. Фисинин В.И., Сурай П. Иммунитет в современном животноводстве и птицеводстве: от теории к практике иммуномодуляции. Птицеводство, 2013, 5: 4-10.

37. Луговая И.С. Влияние аэрозольной обработки куриных яиц естественными метаболитами на комплекс биохимических и зоогигиенических показателей. Птица и птицепродукmы, 2017, 2: 56-59.

38. Азарнова Т.О., Найденский М.С., Хоботьева Д.С., Шарикова Е.А. Применение Рибав для обработки инкубационных яиц. Птицефабрика, 2006, 4: 47-48.

39. Меркулов Г.А. Курс патологической техники. Л., 1969.

40. Лелевич С.В., Курстак И.А., Гриневич Н.И., Воробьев В.В. Основы клинической биохимии. Пособие для студентов медико-диагностического факультета. Гродно, 2013.

41. Кармолиев Р.Х., Ручий О.С., Кармолиев Р.Р., Кочиш И.И., Кармолиев Р.Х., Нестеров В.В. Способ количественного определения проникновения сукцината марганца тетрагидрата в инкубационные яйца кур. ФГОУ ВПО "Московская государственная академия ветеринарной медицины и биотехнологии им. К.И. Скрябина" (РФ). № 2008140854/12. Заявл. 15.10.2008. Опубл. 27.02.2010. Бюл. № 6.

42. Azarnova T.O., Yartseva I.S., Indyukhova Ye.N., Naydenskiy M.S., Zaitsev S.Yu. Effects of the nanostructured complex of biologically active compounds on the free-radical processes and the liver state of the chicken cross Shaver 2000. Journal of Nanomaterials \& Molecular Nanotechnology, 2013, 2(5): 1-3 (doi: 10.4172/2324-8777.1000123).

43. Смердова М.Д., Бородулина И.В. Постнатальный морфогенез иммунокомпетентных органов и печени кур-несушек под влиянием адаптогенов. Аграрный вестник Урала, 2009, 3(57): 80-82.

44. Сурай П.Ф., Бородай В.П. Стрессы в птицеводстве: от понимания механизмов развития к разработке методов защиты. Сучасне птахівництво, 2010, 7: 31-36.

45. Турицына Е.Г. Этиология и механизм развития вторичных иммунодефицитов птиц. Мат. регион. науч.-практ. конф. «Аграрная наука на рубеже веков». Красноярск, 2007, 2: 240-243.

46. Вракин В.Ф., Сидорова М.В. Морфология сельскохозяйственных животных. М., 2000.

ФГБОУ ВО Московская государственная академия ветеринарной медицины и биотехнологий -

Московская ветеринарная академия имени К.И. Скрябина,

109472 Россия, г. Москва, ул. Академика Скрябина, 23,

e-mail: ine98@ya.ru $\bowtie$, azarena@list.ru, zoo-kafedra@yandex.ru,

szaitsev@mail.ru, axis83@mail.ru
Поступила в редакцию 22 января 2018 года

Sel'skokhozyaistvennaya biologiya [Agricultural Biology], 2019, V. 54, № 2, pp. 269-279

\section{HISTOBIOCHEMICAL ASPECTS OF THE EFFECT OF A COMBINATION OF SOME NATURAL METABOLITES ON GENERAL RESISTANCE IN EGG CHICKS}

\section{I.S. Lugovaya, T.O. Azarnova, I.I. Kochish, S.Yu. Zaitsev, M.S. Naidensky, A.A. Antipov}

Skryabin Moscow State Academy of Veterinary Medicine and Biotechnology, 23, ul. Akademika K.I. Skryabina, Moscow, 109472 Russia, e-mail ine98@ya.ru ( $₫$ corresponding author), azarena@list.ru, zoo-kafedra@yandex.ru, szaitsev@mail.ru, axis83@mail.ru

ORCID:

Lugovaya I.S. orcid.org/0000-0002-9925-7070

Azarnova T.O. orcid.org/0000-0001-8760-7603

Kochish I.I. orcid.org/0000-0001-8892-9858

The authors declare no conflict of interests

Received January 22, 2018

Zaitsev S.Yu. orcid.org/0000-0003-1533-8680

Naidensky M.S. orcid.org/0000-0001-8565-1619

Antipov A.A. orcid.org/0000-0002-9667-7029

doi: 10.15389/agrobiology.2019.2.269eng

\section{Abstract}

Industrial incubation of eggs accompanied by various stresses often leads to early embryonic death. For this reason, the ecologically safe methods to prevent negative stressful effects in embry- 
ogenesis are still important. The purpose of this work was to study the effect of natural metabolites on the histological structure of the Bursa fabricii and general resistance of chickens. Studies were performed on eggs of egg cross Shaver 2000 chickens (Gallus gallus) (Enterprise "Ptichnoe", Moscow Province, 2011). 3-4 hours before the eggs were put into the incubator, their shells were treated with an aqueous solution of ethanolamine (colamine), succinic acid and serine $(0.1 ; 0.1$ and $0.2 \%$, respectively) using a spray gun, and on day 19 of incubation $0.1 \%$ aqueous colamine solution was applied. The preparations were pre-dissolved in distilled water at $18-22{ }^{\circ} \mathrm{C}$. The untreated eggs serve as control. Each batch included 544 eggs. The recorded indicators were hatching rates, hatchability and incubation losses, also blood samples were collected to determine the content of immunoglobulins, lysozyme activity and bactericidal activity. Bursa fabricii was collected for histological analysis $(n=5)$ from chickens aged one day. Transovarian treatment of eggs with a complex of biologically active substances containing ethanolamine, succinic acid and serine has positively influenced the viability of embryos and young hens due to leveling of oxidative stress reactions and stimulation of the central components of resistance, i.e. the immune response and non-specific defense of chicks aged one day. Ethanolamine turns into phosphatidylcholine and phosphatidylethanolamine, and serine is metabolized into phosphatidylserine, which are able to neutralize the destruction of cell membranes inevitably arising under free-radical oxidation. Succinic acid, an energy substrate and an antihypoxant, contributes to prevention of the lack of energy (the lack of ATP) in the body, which occurs during critical periods of chick embryogenesis. Applied biologically active substances can optimize the embryo's living conditions during incubation accompanied by technological stresses. The higher viability of chicks of the test group resulted in a decrease of all incubation loss categories with an increase in the chick hatching values and egg hatchability. The content of immunoglobulins responsible for the primary and secondary immune response also increased, which is a demonstration of the immunomodulatory action of the composition used. Immunoglobulin E level remained unchanged, which indicates the absence of hypersensitivity reactions. Ethanolamine, succinic acid and serine also promoted the activation of non-specific defense factors, i.e. blood bactericidal activity and lysozyme, which increased in the test group of chicks too. We also revealed that the composition of biologically active substances positively influence the histoarchitecture of the bursal sac in chicks of the test group, which was confirmed by our histological data. In this, signs of physiological intracellular hyperplasia, as well as the absence of involution processes in the organ have been noted. As the aftereffect of the composition use, the viability of young chicks during the first 60 days of growing increased due to the reduction in mortality. Thus, ethanolamine, succinic acid and serine can prevent oxidative stress and also have a positive effect on general resistance in egg chicks.

Keywords: chicks, embryogenesis, antioxidants, lipoperoxidation, active immunity, bursal sac, chick hatching, ethanolamine, succinic acid, serine.

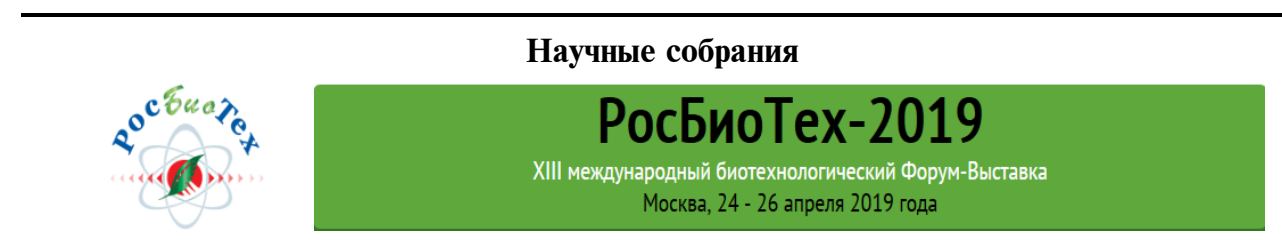

XIII Международный биотехнологический Форум-Выставка «РосБиоТех-2019», ставший традиционным, прошел в Московском государственном университете пищевых производств 2426 апреля 2019 года.

Мероприятие объединило площадку делового и научного форума, интересную выставочную экспозицию, а также конкурсную арену, где молодые российские и зарубежные ученые представили свои научные достижения.

Задачи Форума - обсуждение приоритетов развития биотехнологий для оздоровления населения и высокотехнологичной медицины, современных промышленных производств, продвижения на рынок конкурентоспособной биотехнологической продукции нового поколения.

\section{Тематические направления:}

- биоэнергетика, биотопливо;

- медицинская биотехнология;

- промышленная биотехнология;

- сельскохозяйственная биотехнология; пищевая биотехнология;

- морская биотехнология;

- лесная биотехнология;

- природоохранная (экологическая) биотехнология; экологическая безопасность;

- геронтология;

- «зеленая экономика» - качество жизни и активное долголетие

Контакты и информация: http://www.rosbiotech.com, e-mail: info@rosbiotech.com 